Original Article

\title{
EVALUATION OF ANTIOXIDANT AND CHEMOPREVENTIVE POTENTIAL OF METHANOLIC EXTRACTS OF LEAF OF AEGLEMARMELOS ATTRIBUTES TOWARDS DUCTAL CARCINOMA STUDIED IN MCF7 CELLS
}

\author{
B. ARIRUDRAN ${ }^{*}$, B. JANANI ${ }^{2}$, U. S. MAHADEVA RAO ${ }^{3}$ \\ 1,2Department of Biochemistry, SRM Arts and Science College, Kattankulathur, Kanchipuram District, Tamil Nadu 603203 , ${ }^{3}$ Faculty of \\ Medicine, University of Sultan Zainal Abidin, Terengganu \\ Email: arirudran_1975@yahoo.com \\ Received: 03 Aug 2018 Revised and Accepted: 20 Dec 2018
}

\begin{abstract}
Objective: The objective of the present research work had been made to evaluate the antioxidant potential along with anti-cancer activity of methanolic extracts from the leaf of $A$. marmelos.

Methods: Standard methods for antioxidant potential in terms of DPPH and nitric oxide scavenging assay, and anticancer activity in vitro method (Cytotoxicity/MTT assay and \% of cell viability) by using MCF7 cell line.

Results: Results of antioxidant efficacy revealed that the $\mathrm{IC}_{50}$ value for $\mathrm{DPPH}$ and nitric oxide scavenging assay was considered to be $62.032 \%$, and $20.69 \%$ respectively. The methanolic extract of $A$. marmelos was found to possess enhanced anticancer potential against MCF7 cells. Cytotoxicity activity of MCF7 cells, when treated with methanolic extract of A. marmelos, was found to be $43.42 \%$ at $25 \mu \mathrm{g}, 52.31 \%$ at $50 \mu \mathrm{g}$, $56.31 \%$ at $75 \mu \mathrm{g}$, $58.38 \%$ at $100 \mu \mathrm{g}, 62.25 \%$ at $125 \mu \mathrm{g}$. The $\mathrm{IC}_{50}$ value was found as $49.36 \mu \mathrm{g}$. Toxicity was significantly increased with increased concentration and viability significantly decreased with the increased concentration of methanolic extract of leaf from A. marmelos for MCF7 cell when compared to cyclophosphamide.
\end{abstract}

Conclusion: From the studies, it was postulated that methanolic extract of leaf from A. marmeloshas significant chemopreventive activity. These specific identities will be useful for the identification and authentication of raw drug.

Keywords: Aeglemarmelos, Antioxidants, Anticancer, DPPH, MCF7 Cells

(c) 2019 The Authors. Published by Innovare Academic Sciences Pvt Ltd. This is an open-access article under the CC BY license (http://creativecommons.org/licenses/by/4.0/) DOI: http://dx.doi.org/10.22159/ijpps.2019v11i2.28940

\section{INTRODUCTION}

Cancer is an important public health problem, with significant associated global mortality, disability, and the contribution of risk factors. It is the second leading cause of death in developed countries [1]. There are greater than 200 different types of cancer but, lung cancer, breast cancer, prostate cancer, and large bowel cancer accounts for more than half of all cases [2]. Use of traditional medicine is one of the common practices in India due to their wide spread of pharmacological activities [3]. Reservoir of bioactive compounds is provided in many species of plants. Only a small percentage of which have been examined and was still an important source of anticancer agents. Worldwide effects are on-going to determinenovelanticancer compounds from plants. In recent years, resulting from the fear of side effects, people prefer more and more use of natural plant products for cancer [4]. A. marmelos is a perennial tree, wild in Sub Himalaya tract, central and South India. This plant is usually called as bael in hindi, vilvam in tamil and bilva in sanskrit. It belongs to the family Rutaceae. It is indigenous to India and is used in folk medicines. Ayurvedic practitioners utilize almost all of their parts but the greatest medicinal value ascribed to its fruit especially for its antioxidant pronounced effect [5-8]. Nevertheless, the antioxidant and anticancer activity of leaves from A. marmelos has never been investigated. Hence, this present communication attempt had been evaluated the effectiveness of antioxidant activity (DPPH and nitric oxide radical scavenging assay) along with in vitro anticancer activities (\% of cell viability and cytotoxicity/MTT assay by using MCF7 cell) in methanolic extracts from leaf of $A$. marmelos.

\section{MATERIALS AND METHODS}

\section{Chemicals}

1,1-Diphenyl-2-picrylhydrazyl (DPPH), and ascorbic acid were purchased from sigma chemical Co. (St., Louis, USA). Tertbutyl-4- hydroxytoluene (BHT), folinciocalteu reagent, dimethyl sulfoxide (DMSO) and methanol were purchased from Merck Co. (Germany). Dulbecco's modified eagle's medium (DMEM), fetal bovine serum (FBS), MCF7 cells and 3-(4,5-dimethylthiazol-2-yl)-2,5-diphenyltetrazolium bromide(MTT). All the chemicals and reagents used were of analytical grade purchased from Sigma-Aldrich, India.

\section{Cell lines}

MCF7 Cell lines were purchased from the National Centre For Cell Sciences, Pune, India, through Biozone research technologies Lab, poes road, Teynampet, Chennai, India. The cells were cultured in Dulbecco's modified Eagle's medium containing L-glutamine and 25 mmol 4-[2-hydroxyethyl]-1-piperazine ethane sulfonic acid, penicillin $(100 \mu \mathrm{g} / \mathrm{ml})$, streptomycin $(50 \mu \mathrm{g} / \mathrm{ml})$ and $10 \%$ foetal bovine serum. Cells were maintained at $37{ }^{\circ} \mathrm{C}$ in a humidified incubator in an atmosphere of $5 \% \mathrm{CO}_{2}$.

\section{Plant material}

Fresh leaves materials of A. marmelos were collected from Chennai and Tiruvallur district of Tamilnadu during the month of July 2016. Based on organoleptic macroscopic examination the plant materials were identified and authenticated (Unisza/103/2015) by botanist Mr. Jayaraman West Tambaram, Chennai, using the Flora of Presidency of Madras [9-10] and the voucher specimen was deposited in the department of biochemistry, SRM Arts and Science College, Kattankulathur for further reference.

\section{Preparation of extracts}

The leaves of A. marmelos were collected and allowed to dry at room temperature in the laboratory for a period of $2 \mathrm{w}$ in sunshade, coarsely powdered and weighed. Then it was soaked with methanol for $48 \mathrm{~h}$, the extract was filtered, the filtrate was concentrated by distillation over boil water batty and the last traces of solvent were 
removed under vacuum [11]. Dried crude extracts were stored in sterile amber coloured storage vials in refrigerator until used for antioxidant and cell line work.

\section{Antioxidant assays}

\section{Radical scavenging activity (RSA) using DPPH}

Radical scavenging activity of methanolic extract of leaf from $A$. marmelos was determined by using DPPH radical (1,1-diphenil-2picrylhydrazyl) according to the standard method with slight modification [12]. Stock solution of methanolic extract from the leaf of A. marmelos was prepared at the concentration of $10 \mathrm{mg} / \mathrm{ml}$. Different concentrations of the extract $(20,40,60,80,100 \mu \mathrm{g})$ were added, to an equal volume of the methanolic solution of DPPH $(0.1$ mmol). Ascorbic acid was used as a standard control. Blank was of pure methanol and control sample was methanol along with DPPH solution. The DPPH $[100 \mu \mathrm{l}(0.1 \%)]$ with BTH $100 \mu \mathrm{l}(0.16 \%)$ was used as standard. DPPH (0.1\%) freshly prepared were used as the control. The reaction mixture was shaken vigorously and covered with aluminium foil and incubated for $30 \mathrm{~min}$ in the dark at room temperature; the absorbance was recorded at $517 \mathrm{~nm}$ against a blank by using a spectrophotometer. The experiment was repeated for three times. The percentage Free radical scavenging activities of test samples and the positive control were expressed in terms of $\mathrm{IC}_{50}$ values, which is the concentration of a sample required to decrease the absorbance at $517 \mathrm{~nm}$ by $50 \%$ compared to the control response. Annihilation activity of free radicals was calculated in percentage inhibition according to the following formula:

$$
\% \text { inhibition of DPPH radical scavenging activity }=\frac{\mathrm{A} 0-\mathrm{A} 1}{\mathrm{~A} 0} * 100
$$

Where A0 is the absorbance of DPPH radical+methanol; A1 is the absorbance of DPPH radical+leaf extract.

\section{Nitric oxide scavenging activity}

The nitric oxide assay was performed as described previously with slight modification [13]. Stock solutions of leaf extracts were prepared in the concentration of $1 \mathrm{mg} / \mathrm{ml}$. Standard ascorbic acid was produced in the concentration of $(25 \mu \mathrm{l})(0.16 \%)$. The reaction mixture consists of $2 \mathrm{ml}$ of sodium nitroprusside $(10 \mathrm{mmol})$ and 0.1 $\mathrm{ml}$ of phosphate buffered saline with different concentrations 25, 50 and $100 \mu \mathrm{g}$ of samples and incubated at $25{ }^{\circ} \mathrm{C}$ for $15 \mathrm{~min}$. After incubation, $0.5 \mathrm{ml}$ of the reaction mixture was mixed with $1 \mathrm{ml}$ of $1 \%$ sulphanilamide and allowed to stand for $5 \mathrm{~min}$ for complete diazotization, to this $1 \mathrm{ml}$ of $2 \%$ phosphoric acid and followed by 1 $\mathrm{ml}$ of $0.1 \%$ naphthyl-ethylene-di-amine di-hydrochloride was added, mixed well and allowed to stand for $30 \mathrm{~min}$ at $25^{\circ} \mathrm{C}$. Blank consists of all the reagents except for the extract or standard solution is substituted with water. The absorbance of these solutions was measured at $540 \mathrm{~nm}$ against the corresponding blank solution using a spectrophotometer. The experiment was repeated for three times. Scavengers of nitric oxide compete with oxygen, leading to reduced production of nitrite ions. Pink colored chromophore controls were expressed in terms of $\mathrm{IC}_{50}$ values, which is the concentration needed to decrease nitric oxide induced by $50 \%$ in comparison to the control response. The annihilation activity of free radicals was calculated in percentage inhibition according to the following formula:

$\%$ inhibition of nitric oxide radical scavenging activity

$$
=\frac{\mathrm{A} 0-\mathrm{A} 1}{\mathrm{~A} 0} * 100
$$

Where A0 was the absorbance of control; $\mathrm{A} 1$ was the absorbance in the presence of extract and standard ascorbic acid.

\section{Anticancer activity \\ In vitro assay for cytotoxicity (MTT assay)}

MTT (3-(4,5-dimethylthiazol-2-yl)-2,5-diphenyl-tetrazolium bromide) assay [14] is based on the ability of living but not dead cells to reduce a yellow tetrazolium dye to a purple formazan product. Cells were maintained in DMEM, supplemented with $10 \% \mathrm{FBS}$, at $37^{\circ} \mathrm{C}$ in a humidified atmosphere with $5 \% \mathrm{CO}_{2}$. MCF7 cells were plated in 96-well flat bottom tissue culture plates at a density of approximately $1.2 \times 10^{4} \mathrm{Cells}$ /well and allowed to attach overnight at $37{ }^{\circ} \mathrm{C}$. Methanolic leaf extract ofAeglemarmelos $1 \mathrm{mg} / \mathrm{ml}$ was prepared as a stock. The medium was later discarded and cells were incubated with different concentrations of the samples $(25,50,75$, 100 and $125 \mu \mathrm{l}$ ) for $24 \mathrm{~h}$. After the incubation, the medium was discarded and $100 \mu \mathrm{l}$ fresh medium was added with $10 \mu \mathrm{l}$ of MTT (5 $\mathrm{mg} / \mathrm{ml}$ ). After $4 \mathrm{~h}$, the medium was discarded and $100 \mu \mathrm{l}$ of DMSO was added to dissolve the formazan crystals. Then, the absorbance was read at $570 \mathrm{~nm}$ in a microtitre plate reader. Cyclophosphamide was invoked as a positive control. Medium along with cells (untreated) serves as a control. Cell survival was calculated by the following formula: Viability $\%=$ (Test OD/Control OD) X 100. Cytotoxicity $\%=100$-Viability $\%$.

\section{RESULTS AND DISCUSSION}

DPPH: Radical scavenging activity (RAS) using 1,1-diphenyl-2picrylhydrazyl was a widely used method to evaluate the free radical scavenging ability of various samples including plant extract. The principle of the DPPH method is based on the reduction of DPPH in the presence of a hydrogen donating antioxidant owing to the formation of diphenylpicrylhydrozine. Extracts reduced the colour of DPPH owing to the power of hydrogen donating ability [15].

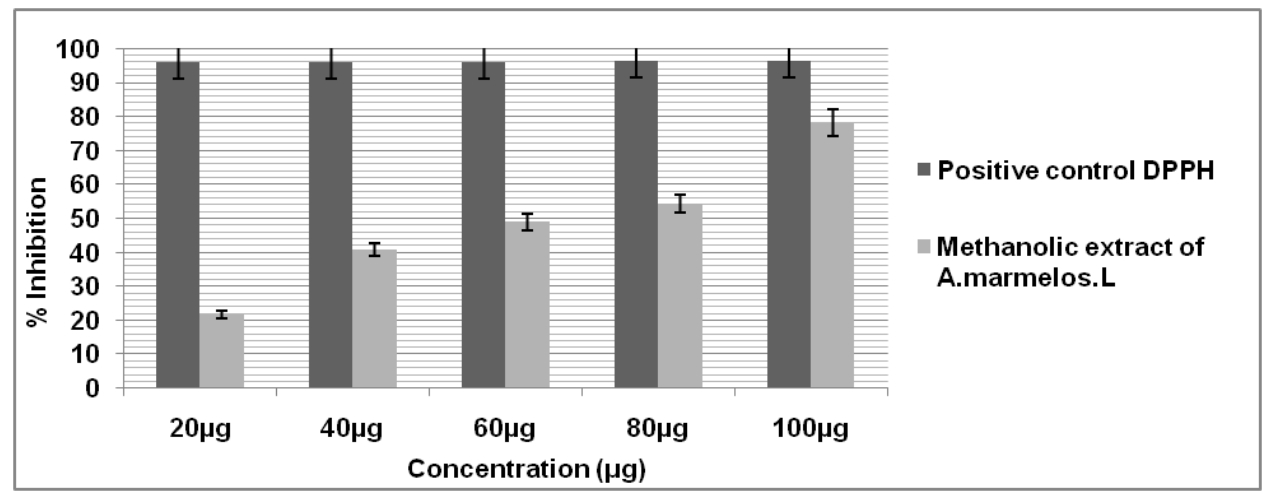

Fig. 1: DPPH radical scavenging of methanolic extract of $A$. marmelos, $n=$ number of determinations (2), SD = Standard Deviation (mean $\pm S D$ ), for different concentration in each group. Statistical significance $p$ value $(<0.05)$ compared with standard

Fig. 1 showed DPPH anion scavenging power of extracts. Discolouration of violet with DPPH to Yellow clearly demonstrated that the methanolic extract of leaf from A. marmelos has excellent antioxidant activity. The percentage of inhibition against the concentration of methanolic extract of leaf from A. marmelos was found to be $21.77 \%$ at $20 \mu \mathrm{g} / \mathrm{ml}, 40.82 \%$ at $40 \mu \mathrm{g} / \mathrm{ml}, 48.88 \%$ at $60 \mu \mathrm{g} / \mathrm{ml}, 54.30 \%$ at $80 \mu \mathrm{g} / \mathrm{ml}$ and $78.11 \%$ at $100 \mu \mathrm{g} / \mathrm{ml}$ respectively when compared to that of standard BTH. The half maximal 
inhibitory concentration $\mathrm{IC}_{50}$ was found to be $62.032 \%$. This result shows that the maximum free radical scavenging potential was obtained after $30 \mathrm{~min}$ for methanolic extract of leaves from $A$. marmelos. It is evident that the extract did show proton donating ability and hence it could serve as a free radical inhibitor and primary antioxidant. Usually higher total phenol and flavonoids contents lead to better DPPH-scavenging activity [16-19]. In the present study the DPPH radical scavenging activity of methanolic extract of leaves of $A$. marmelos shows significant scavenging activity, it may be due to the presence of high amount of phenolic compounds, flavonoids, and tannins. Hence the result empathise that methanolic extract of leaves from A. marmelos has the significant anti-oxidant property it may be due to potential hydrogen donating ability.

\section{Nitric oxide}

The available nitric oxide radical is linked with various carcinomas and inflammatory conditions [20]. Nitric oxide can react rapidly in the intracellular environment to form nitrate, nitrite, and Snitrosothiols. These metabolites play a key role in mediating many xenotoxic effects such as DNA damage. Nitric oxide causes DNA damage via peroxynitrite. In addition to reactive oxygen species, nitric oxide is also involved in inflammation, cancer and other pathological conditions [21].

Table 1: Nitric Oxide scavenging activity of methanolic extract of $A$. marmelos

\begin{tabular}{lll}
\hline Concentration $(\boldsymbol{\mu g})$ & \% of Inhibition \\
\cline { 2 - 3 } & Standard ascorbic acid & Methanolic extract of $\boldsymbol{A}$. marmelos \\
\hline 20 & 70.34 & 49.92 \\
40 & 71.89 & 56.76 \\
60 & 74.38 & 65.52 \\
80 & 79.45 & 77.53 \\
100 & 90.80 & 80.21 \\
\hline
\end{tabular}

$\mathrm{n}=$ number of determinations $(2), \mathrm{SD}=$ Standard Deviation (mean \pm SD), for different concentration in each group. Statistical significance $\mathrm{p}$ value $(<0.05)$ compared with standard.

Nitric Oxide generated from sodium nitroprusside reacts with oxygen to form nitrite. The extract directly competes with oxygen to react with nitric oxide and thereby inhibits the nitrite formation. In the present study, the \% of nitric oxide scavenging activity of methanol extract of leaf of $A$. marmelos was found to be increased with increased in concentration of extract significantly when compared with the standard. The table 1 shows that the percentage of nitric oxide radical inhibition of the sample with concentration ranging from $20,40,60,80$ and $100 \mu \mathrm{g} / \mathrm{ml}$ was found to be $49.92 \%$, $56.76 \%, 65.52 \%, 77.53 \%$ and $80.21 \%$ respectively. The half maximal inhibitory concentration $\mathrm{IC}_{50}$ was found to be $20.69 \%$. This result shows that the methanolic extract of leaves from $A$. marmelos had significant antioxidant property. In the present study, the nitric oxide scavenging ability of a methanolic extract of leaves of $A$. marmelos is highly significant when compared with standard ascorbic acid. This positive result confirmed that theethanolic extract of leaves of $A$. marmelos was capable of scavenging nitric oxide ion due to the presence of phenolic compounds, tannin contents. Hence this result emphasizes that methanolic extract of leaves of $A$. marmelos may have potential anticancer and antiinflammatory property [22]. Several concentrations ranging from $20-100 \mu \mathrm{g} / \mathrm{ml}$ of methanolic extract of leaf from $A$. marmelos were tested for their antioxidant activity using in vitro models. Hence the result obtain emphasize that leaf of $A$. marmelos may have significant antioxidant or free radical scavengers property. It was observed that free radicals were scavenged by the test compounds in concentration-dependent manner in both methods. This result may provide scientifically support for the use of plant materials for the treatment of cancer related diseases in traditional medicine especially for ductal carcinoma.

\section{MTT assay for cytotoxicity of MCF7 cells}

The anticancer activity of samples on MCF7cells were determined by the MTT assay was used to measure the cytotoxicity [23]. Cells $(1 \times 105 /$ well $)$ were plated in $0.2 \mathrm{ml}$ of medium/well in 96 -well plates. In MTT assay the medium from the wells was removed carefully after incubation. Each well was washed with MEM (w/o) FCS for 2-3 times and $200 \mu \mathrm{l}$ of MTT $(5 \mathrm{mg} / \mathrm{ml})$ was added. The plates were incubated for 6-7 $\mathrm{h}$ in $5 \% \mathrm{CO}_{2}$ incubator for cytotoxicity. After incubation, $1 \mathrm{ml}$ of DMSO (solubilizing reagent) was added to each well and mixed well by micropipette and left for $45 \mathrm{sec}$. Presence of viable cells was visualized by the development of purple color due to the formation of formazan crystals. The suspension was transferred to the cuvette of a spectrophotometer and the OD (optical density) values were read at $595 \mathrm{~nm}$ by using DMSO as a blank. Measurements were performed and the concentration required for $50 \%$ inhibition of viability $\left(\mathrm{IC}_{50}\right)$ was determined graphically standard graph was plotted by taking, the concentration of the drug in $\mathrm{X}$-axis and relative cell viability in $\mathrm{Y}$-axis. Cell viability $(\%)=$ Mean OD/Control OD x 100\%



Fig. 2: Percentage of cell viability against a methanolic extract of $A$. marmelos, $n=$ number of determinations (2), SD = Standard Deviation (mean \pm SD), for different concentration in each group. Statistical significance p-value $(<0.05)$ compared with standard 
The fig. 2 shows that the viability of MCF7 cell when treated with the methanolic extract of $A$. marmelos was found to be $56.58 \%$ at $25 \mu \mathrm{g}$; $47.69 \%$ at $50 \mu \mathrm{g}, 43.69 \%$ at $75 \mu \mathrm{g}, 41.62 \%$ at $100 \mu \mathrm{g}, 37.75 \%$ at $125 \mu \mathrm{g}$. Viability of MCF7 cell was significantly decreased with the increase concentration of the methanolic extract of leaf from $A$. marmelos at $125 \mu \mathrm{g}$ when compared to cyclophosphamide. The IC 50 value of the given sample is $49.36 \mu \mathrm{g}$. It was formerly reported that extract from A. marmelos has an anti-proliferative effect on cell line MCF7 [24], inhibits the proliferation of transplanted ehrlich ascites carcinoma bearing swiss albino mice [25].

Table 2: Percentage of cytotoxicity against a methanolic extract of $A$. marmelos

\begin{tabular}{lll}
\hline Concentration $(\boldsymbol{\mu g})$ & \% of inhibition & Methanolic extract of $\boldsymbol{A}$. marmelos \\
\cline { 2 - 3 } & Cyclophosphamide & $43.42 \%$ \\
25 & 78.17 & $52.31 \%$ \\
50 & 79.18 & $56.31 \%$ \\
75 & 81.29 & $58.38 \%$ \\
100 & 82.18 & $62.25 \%$ \\
\hline
\end{tabular}

$\mathrm{n}=$ number of determinations $(2), \mathrm{SD}=$ Standard Deviation (mean \pm SD), for different concentration in each group. Statistical significance $\mathrm{p}$ value $(<0.05)$ compared with a standard.

The table 2 shows that cytotoxicity activity of MCF7 cells, when treated with the methanolic extract of A. marmelos, was found to be $43.42 \%$ at $25 \mu \mathrm{g}, 52.31 \%$ at $50 \mu \mathrm{g}, 56.31 \%$ at $75 \mu \mathrm{g}, 58.38 \%$ at $100 \mu \mathrm{g}, 62.25 \%$ at $125 \mu \mathrm{g}$. Toxicity significantly increased with the increased concentration of the methanolic extract of leaf from $A$. marmelos at $125 \mu \mathrm{g}$ when compared to Cyclophosphamide. The $\mathrm{IC}_{50}$ value of the given sample is $125 \mu \mathrm{g}$. Early report said that methanol, ethyl acetate and $n$-hexane extract of leaves of AeglemarmelosorBael, showed potent cytotoxic activity with $\mathrm{LC}_{50}$ values of $4.482,5.278$ and $5.278 \mu \mathrm{g} / \mathrm{ml}$ respectively whereas the standard vincristine sulfate showed $3.364 \mu \mathrm{g} / \mathrm{ml}$. The three extracts of leaves of $A$. marmelos possessed significant antioxidant and cytotoxic potentials in this experiment [26]. From this, in vitro cell line studies it was found that methanolic extract of leaf from A. marmelos was found to be non-toixc to normal cells, probably anti-proliferative and cytotoxic effect against MCF7 cells.

\section{CONCLUSION}

Result obtains from this research work emphasize that leaf of $A$. marmelos may have significant antioxidant or free radical scavengers properties along with the significant chemo-preventive activity. Hence in conclusion utilization or increased consumption of this plant product will be advantageous to mankind, and it will contribute to the prevention of chronic lifestyle along with several kinds of oxidative degenerative disease such as ductal carcinoma. Further investigations on health-promoting aspects in animal models in the future will be made.

\section{ACKNOWLEDGMENT}

The authors would like to thankful to Mrs. Florida Tilton and staff members of biozone research technologies Lab, poes road, Teynampet, Chennai, India, for providing laboratory facilities and technical assistance.

\section{AUTHORS CONTRIBUTIONS}

The Corresponding author, B. Arirudran supervised the experimental work and wrote the manuscript. B. Janani took place in the laboratory work and data collections. US Mahadeva Rao reviewed the manuscript and put necessary efforts to improve the quality of the manuscript.

\section{CONFLICT OF INTERESTS}

We declare that there were no conflicts of interest

\section{REFERENCES}

1. Anthony J Maxwell, Karen Clements, Bridget Hilton, David J Dodwell, Andrew Evans, Olive Kearins, et al. Risk factors for the development of invasive cancer in unselected ductal carcinoma in situ. Eur J Surgical Oncol 2018;44:429-35.

2. Peedell C. Concise clinical oncology. Elsevier: Philadelphia USA; 2005. p. 3-5.

3. Asolkar LV, Kakkar KK, Charkre OJ. Second supplements to glossary of Indian medicinal plants with active principles, Part-
I (A-K) (1965-1981), Published by Publications and Information Directorate (CSIR), New Delhi, India; 1992. p. 217.

4. Vaiyapuri Subbarayan Periasamy, Jegan Athinarayanan, Ali A Alshatwi, Ultrasonics Sonochemistry. Anticancer activity of an ultrasonic nanoemulsion formulation of Nigella sativa L Essential oil on human breast cancer cells. Ultrason Sonochem 2016;31:449-55.

5. WHO Traditional medicine: Growing needs and potential, WHO Policy perspectives on medicines. World Health Organisation, Geneva; 2002. p. 1.

6. Mandal S, Yadav S, Yadav S, Nema RK. Antioxidants: a review. J Chem Pharm Res 2009;1:102-4.

7. Ajitha M, Rajnarayana K. Role of oxygen free radicals in human disease. Indian Drugs 2001;38:545-54.

8. Halliwell B, Aeschbach R, Loliger J, Aruom OI. The characterization of antioxidants. Food Chem Toxicol 1995;33:601-17.

9. Gamble JS. The Flora of the presidency of madras. Botanical Survey India 1967;2:524.

10. Brain KR, Turner TD. The practical evaluation of phytopharmaceuticals Bristol: Wright Scientehnica; 1975. p. 78-80.

11. Gupta AP, Verma RK, Gupta MM, Sunilkumar. Estimation of plumbagin using high performance, thinlayer chromatography. J Med Arom PI Sci 1999;21:661-3.

12. Nenadis N, Tsimidou M. Observations on the estimation of scavenging activity of phenolic compounds using rapid 1, 1diphenyl-2-picrylhyrazyl [DPPH!]. J Am Oil Chem Soc 2002;79:1191-5.

13. Sreejayan N, Rao MNA. Nitric oxide scavenging by curcuminoids. J Pharm Pharmacol 1997;49:105-107.

14. Mosmann T. Rapid colorimetric assay for cellular growth and survival: application to proliferation and cytotoxicity test. J Immunol Methods 1983;65:55-63.

15. Ebrahimzadeh MA, Pourmorad F, Hafezi S. Antioxidant activities of Iranian corn silk Turk. J Biol 2008b;32:43-9.

16. Ebrahimzadeh MA, Bahramian F. Antioxidant activity of Crataeguspentagina subspecies Elbursis fruits extracts are used in traditional medicine in Iran Pak. J Biol Sci I 2009a;12:413-9.

17. Ebrahimzadeh MA, Ehsanifar S, Eslami B. Sambucusebuluselburensis fruit: a good source for antioxidants. Pharmacogn Mag 2009b;4:213-8.

18. Ebrahimzadeh MA, Nabavi SM, Nabavi SF, Eslami B. Antioxidant activity of aqueous extract of Pyrusboissieriana fruit. Pharmacologyonline 2009c;1:1318-23.

19. Bashir Ado Ahmad, Khamsah Suryati Mohd, Muhammad Abdurrazak, US Mahadeva Rao, Thant Zin. Phytochemical screening, the antioxidant activity of pure syringinin comparison to various solvents extracts of Musa paradisiaca (Banana) (Fruit and flower) and total phenolic contents. Int J Pharm Pharm Sci 2015;7:242-7.

20. Tylor BS, Kion YM, Wang QI, Sharpio RA, Billiar TR, Geller DA. Nitric oxide Down-regulates hepatocyte-inducible nitric oxide synthase gene expression. Arcg Surg 1997;132:1177-83. 
21. Nabavi SM, Ebrahimzadeh MA, Nabavi SF, Hamidinia A Bekhradnia AR. Determination of antioxidant activity, phenol and flavonoids content of Parrotiapersica Mey. Pharmacol Online 2008a;2:560-7.

22. Benni JM, Jayanthi MK, Suresha RN. Evaluation of antiinflammatory activity of Aeglemarmelos (Bilwa) root. Indian J Pharmacol 2011;43:393-7.

23. Horiuchi N, Nakagava K, Sasaki Y, Minato K, Fujiwara Y, Nezu K, et al. In vitro antitumor activity of mitomycin C derivative (RM49) and a new anticancer antibiotic (FK973) against lung cancer cell lines determined by tetrazolium dye (MTT) assay. Cancer Chemother Pharmacol 1988;22:246-50.
24. Lambertini E, Piva R, Khan MT, Lampronti I, Bianchi N, et al. Effects of extracts from Bangladeshi medicinal plants on in vitro proliferation of human breast cancer cell lines and expression of estrogen receptor alpha gene. Int $\mathrm{J}$ Oncol 2004:24:419-23.

25. Jagetia GC, Venkatesh P, Baliga MS. Aeglemarmelos correa inhibits the proliferation of transplanted Ehrlich ascites carcinoma in mice. Biol Pharm Bull 2005;28:58-64.

26. Kaniz Fatima Urmi, Ashraf Uddin Chowdhury, Farhana Diba, Khandaker Ashfaqur Rahman. Evaluation of antioxidant and cytotoxic potential of different extracts from the leaves of Aeglemarmelos. Res J Pharm Tech 2013;6:384-7. 